\title{
ANALISIS UNIT COST MAHASISWA DALAM PERENCANAAN PEMBIAYAAN PENDIDIKAN PADA PROGRAM PASCASARJANA (PPS) DI UNIVERSITAS TERBUKA
}

\author{
Tita Rosita (tita@ut.ac.id) \\ Mohamad Nasoha \\ Suci Madiarti Isman \\ Universitas Terbuka
}

\begin{abstract}
ABSTRAK
Penelitian mengenai Analisis Unit Cost Mahasiswa Dalam Perencanaan Pembiayaan Pendidikan Pada Program Pascasarjana (PPS) di Universitas Terbuka ini bertujuan untuk mengetahui biaya yang harus dikeluarkan mahasiswa yang mengikuti program PPs-UT, agar didapatkan satuan riil pembiayaan ini dengan menganalisis 3 aspek unit cost, yakni fixed cost (biaya tetap), variable cost (biaya variabel), dan opportunity cost yang menjadi tanggung jawab mahasiswa. Untuk jangka panjangnya, diharapkan hasil penelitian ini dapat dijadikan sebagai pedoman dan perencanaan pembiayaan pendidikan bagi calon mahasiswa yang ingin melanjutkan pendidikan pada Pendidikan Jarak Jauh Program Pascasarana Universitas Terbuka sesuai dengan karakter UPBJJ-UT masing-masing wilayah. Penelitian ini dilaksanakan pada program PPs UT, dengan sampel mahasiswa PPs UT pada semester IV. Pengambilan sampel untuk penelitian ini menggunakan proporsional random sampling. Metode yang digunakan dalam penelitian ini yaitu metode deskriptif dengan pendekatan kualitatif. Hasil penelitian menunjukkan bahwa biaya tetap (fixed cost) memiliki besaran nilai yang sama untuk setiap item yang harus dibayarkan, kecuali untuk biaya registrasi mahasiswa baru, biaya ujian sidang, serta biaya Bimbingan Tesis Residensial (BTR). Untuk biaya variabel, besarannya tergantung dari lokasi mahasiswa berasal, terutama terkait dengan tutotial tatap muka dan tanggungan hidup. Untuk biaya kesempatan (opportunity cost), mahasiswa merasa tidak kehilangan kesempatan untuk bekerja selama mengikuti perkuliahan di PPs UT, dikarenakan sistem kuliah online serta tutorial tatap muka (TTM) yang diadakan hari Sabtu dan Minggu tidak mengganggu jadwal pekerjaan mereka. Sementara itu, untuk merencanakan pendidikan mereka ke depan, mahasiswa merencanakan pembiayaan pendidikannya dengan menyisihkan penghasilan.
\end{abstract}

Kata kunci: fixed cost, opportunity cost, perencanaan pembiayaan pendidikan, unit cost, variabel cost

\begin{abstract}
Research on Unit Cost Analysis of Students in Planning Graduate Program In Education Financing (PEF) at the Open University aims to determine the costs of students who take the program PPs-UT, in order to obtain this financing real terms by analyzing three aspects of the unit cost, which is fixed costs (fixed costs), variable cost (variable cost), and opportunity costs are the responsibility of the student. For the long term, the expected results of this study can serve as guidelines and financial planning education for prospective students who wish to continue their education in Distance Education Program in accordance
\end{abstract}


with the Open University Pascasarana UPBJJ-UT character of each area. The research was conducted at UT PPS program, with sample PPS UT students in semester IV. Sampling for this study using proportional random sampling. The method used in this research is descriptive method with qualitative approach. The results showed that the fixed costs (fixed cost) has the same magnitude value for each item to be paid, except for the new student registration fee, examination fee hearing, as well as the cost Thesis Guidance Residential (BTR). For the variable costs, the amount depending on the location of the students are, especially related to tutotial face to face and dependents live. For the opportunity cost (opportunity cost), students feel not lose the opportunity to work during the lecture at UT PPs, because the online college system as well as face to face tutorials (TTM) which was held on Saturday and Sunday do not interfere with their work schedule. Meanwhile, to plan their future education, student education financing plan by setting aside income.

Keywords: fixed costs, opportunity costs, financial planning education, unit cost, variable cost

Pendidikan jarak jauh merupakan suatu proses pendidikan tanpa pembatas dinding sekolah (education without walls). Terkait dengan karakteristik pendidikan jarak jauh seperti dijelaskan di atas, maka terdapat nilai tambah yang diberikan sistem pendidikan jarak jauh yang diselenggarakan oleh Universitas Terbuka (UT) yaitu peserta didik tidak harus meninggalkan pekerjaan. Sejalan dengan kebutuhan terhadap pendidikan tinggi di masyarakat, maka mulai tahun 2004 UT menyelenggarakan Program Pascasarjana (PPS) yang diselenggarakan di beberapa UPBJJ-UT. Penyelenggaraan PPs UT dilaksanakan dengan 2 model pembelajaran yaitu pembelajaran melalui tutorial online sepanjang semester dengan minimal 8 kali akses insiasi dan tutorial tatap muka sebanyak 4 kali pertemuan dan 3 tugas yang wajib diikuti oleh mahasiswa.

Penelitian sebelumnya yang dilaksanakan di UT dengan judul penelitian Biaya Penyelenggaraan Sistem Pendidikan Jarak Jauh: Benarkah Lebih Murah? yang dilaksanakan oleh Tian Belawati \& Durri Andriani ${ }^{1}$, dijelaskan bahwa biaya pendidikan jarak jauh ditentukan oleh kedua jenis media yang ditawarkan dan jumlah mahasiswa dilayani. Biaya untuk penyelenggaraan pendidikan jarak jauh termasuk biaya institusional dan biaya personal (yang dikeluarkan oleh mahasiswa). Di Universitas Terbuka (UT) proporsi terbesar dari biaya institusional adalah untuk pembelajaran dan pendidikan (56\%), diikuti oleh administrasi umum (41\%). Dalam hal biaya personal, biaya kuliah yang dibayarkan oleh mahasiswa untuk belajar di UT lebih rendah dibandingkan dengan universitas tatap muka. Hasil penelitian tersebut memberikan gambaran secara umum namun belum mengungkap kondisi yang dihadapi oleh mahasiswa PPs UT sehingga masih perlu dilakukan penelitian secara spesifik pada Program Magister PPs UT.

Di samping itu, penelitian terdahulu yang dilakukan di International Data Corporation (IDC) di tahun 1998,60\% dari semua universitas di Amerika Serikat telah mengenalkan bentuk belajar jarak jauh dan diperkirakan pada tahun 2002 bentuk ini akan mencapai 90\% (Oshima, 158, 2001). Di Amerika Serikat, e-learning, yang merupakan satu tipe belajar jarak jauh menggunakan komputer, telah tumbuh rata-rata pertahun $42 \%$ untuk lima tahun terakhir.

Sehubungan dengan permasalahan di atas, maka penelitian ini akan membahas mengenai perencanaan pembiayaan pendidikan pada program pascasarjana PTJJ Universitas Terbuka yang

\footnotetext{
1 Universitas Terbuka dalam http://lppm.ut.ac.id/ptj//PTJJ\%20Vol\%203.1\%20maret\%202002/31tian.htm
} 
terkait dengan Analisis Unit Cost Mahasiswa Dalam Perencanaan Pembiayaan Pendidikan Pada Program Pascasarjana (PPs) Di Universitas Terbuka agar dapat direncanakan pola pembiayaan bagi mahasiswa S2 dengan karakteristik wilayah UPBJJ. Adapun yang menjadi pertanyaan penelitian adalah berapa besaran fixed cost/ biaya tetap, variable cost/ biaya variable, serta opportunity cost mahasiswa Pascasarjana selama mengikuti pendidikan jarak jauh di UT?. Manfaat dari penelitian analisis unit cost ini yakni diharapkan luaran penelitian atas 3 aspek perhitungan unit cost yang diperoleh dapat dijadikan sebagai acuan/pedoman dalam perencanaan pola pembiayaan pendidikan yang disesuaikan dengan UPBJJ masing-masing wilayah.

\section{METODOLOGI}

Penelitian dilaksanakan di UPBJJ yang menyelenggarakan program Pascasarjana. Populasi dalam penelitian ini adalah seluruh mahasiswa program Pascasarjana Universitas Terbuka semester 4. Pengambilan sampel untuk penelitian ini dilakukan secara acak/ random sampling/ pengambilan sample. Pada penelitian ini diambil sampel sebanyak 10\% dari jumlah populasi sebanyak 917 mahasiswa sehingga jumlah sampel yang akan diteliti adalah sebanyak 92 orang mahasiswa serta dibagi dalam 2 lingkup wilayah yang didasarkan pada karakteristiknya, yakni Pulau Jawa dan luar Pulau Jawa.

Metode dalam penelitian ini menggunakan metode deskriptif dengan pendekatan kualitatif.Metode deskriptif menurut Sugiyono (2008) adalah statistika yang berfungsi untuk mendiskripsikan atau memberi gambaran terhadap obyek yang diteliti melalui data sampel atau populasi sebagaimana adanya, tanpa melakukan analisis dan membuat kesimpulan yang berlaku untuk umum.

Menurut Izzak Laktunussa (1988:104) "Penelitian kuantitatif yaitu penelitian yang menggunakan metode bilangan untuk mendeskripsikan observasi suatu objek atau variable dimana bilangan menjadi bagian dari pengukuran." Pendekatan kuantitatif digunakan untuk mengukur tiaptiap variabel yang ada dalam penelitian sehingga diketahui tingkat keterhubungan melalui teknik perhitungan statistik.

\section{HASIL}

Total kuesioner yang disebar adalah sebanyak 92 kuesioner, yakni terdiri atas biaya tetap (fixed cost) dan biaya variabel (variable cost) yang terbagi atas 4 semester serta biaya kesempatan (opportunity cost) berupa form pertanyaan wawancara yang disebar kepada mahasiswa PPs UT. Sementara itu, tingkat respon dari partisipan mencapai $100 \%$. Akan tetapi, setelah dilakukan pemeriksaan dalam rangka pemasukan data, hanya sekitar 73 angket dari total keseluruhan angket yang dapat diolah sehingga diperoleh respon rate sebesar 79,35\%.

Hasil penelitian dibedakan atas identitas mahasiswa yang mengisi kuesioner pertanyaan. Dalam penelitian ini, terbagi atas 2 yakni untuk mahasiswa yang berasal dari Pulau Jawa dan mahasiswa yang berasal dari luar Pulau Jawa. Berikut adalah penjelasan variabel penelitian:

\section{a. Pulau Jawa}

Mahasiswa yang mengisi kuesioner dan dapat diolah yang berasal dari Pulau Jawa terdiri atas 19 mahasiswa, yakni berasal dari UPBJJ UT Semarang, UPBJJ UT Bandung dan UPBJJ UT Jakarta. 
Gambaran terkait dengan rata-rata biaya tetap (fixed cost) yang dikeluarkan oleh mahasiswa untuk masing-masing semester, yakni dari semester 1 sampai dengan semester 4 dapat dijabarkan pada Tabel 1.

Tabel 1. Rata-Rata Biaya Tetap (Fixed Cost) Mahasiswa UPBJJ UT Pulau Jawa

\begin{tabular}{lr}
\hline Pertanyaan & Rata-Rata (Rp.) \\
\hline Semester 1 & \\
Biaya Tes Masuk/ Admisi & 300.000 \\
Biaya Registrasi Per Semester/ SPP & 6.300 .000 \\
Biaya mengikuti Kegiatan Orientasi Mahasiswa Baru (OSMB) & 166.667 \\
Biaya Registrasi Ulang Mata Kuliah & 500.000 \\
Biaya seminar per semester & 500.000 \\
Biaya mengikuti perkuliahan umum per semester & 100.000 \\
Biaya mengikuti Tutorial Tatap Muka (TTM) & 3.300 .000 \\
Semester 2 & \\
Biaya Registrasi Per Semester/ SPP & $6,300,000$ \\
Biaya Registrasi Ulang Mata Kuliah & 785.714 \\
Biaya seminar per semester & 100.000 \\
Biaya mengikuti perkuliahan umum per semester & - \\
Biaya mengikuti Tutorial Tatap Muka (TTM) & 3.900 .000 \\
Semester 3 & \\
Biaya Registrasi Per Semester/ SPP & 6.300 .000 \\
Biaya Registrasi Ulang Mata Kuliah & - \\
Biaya seminar per semester & 100.000 \\
Biaya mengikuti perkuliahan umum per semester & - \\
Biaya mengikuti Tutorial Tatap Muka (TTM) & 3.000 .000 \\
Semester 4 & \\
Biaya Registrasi Per Semester/ SPP & 6.300 .000 \\
Biaya Registrasi Ulang Mata Kuliah & - \\
Biaya seminar per semester & 100.000 \\
Biaya mengikuti perkuliahan umum per semester & 100.000 \\
Biaya mengikuti Tutorial Tatap Muka (TTM) & - \\
Biaya BTR 1 & 1.875 .000 \\
Biaya BTR 2 & 1.325 .000 \\
Biaya Ujian Sidang & $5,406.250$ \\
Biaya wisuda & 936.429 \\
\hline Sumber: Hasil penelitian, diolah penulis (2013). & \\
\hline
\end{tabular}

Berdasarkan hasil penelitian, rata-rata nilai tertinggi untuk variabel fixed cost selama 4 semester disimpulkan bahwa pada semester 4 memerlukan banyak biaya pengeluaran dibandingkan semester yang lainnya. Adapun biaya rata-rata tertinggi yakni untuk pembayaran SPP mahasiswa, yang berkisar sebesar Rp 6.300.000,- (pembulatan). Sedangkan biaya rata-rata terendah yakni pada biaya seminar per semester yakni sebesar Rp 100.000,-. 
Gambaran terkait dengan rata-rata biaya variabel (variable cost) yang dikeluarkan oleh mahasiswa untuk masing-masing semester, yakni dari semester 1 sampai dengan semester 4 dapat dijabarkan pada Tabel 2.

Tabel 2. Rata-Rata Biaya Variabel (Variable Cost) Mahasiswa UPBJJ UT Pulau Jawa

\begin{tabular}{|c|c|}
\hline Pertanyaan & Rata-Rata \\
\hline \multicolumn{2}{|l|}{ Semester 1} \\
\hline Biaya Pembelian buku mata kuliah per semester di luar modul & 180,263 \\
\hline Biaya Pembelian alat tulis (termasuk tinta printer, kertas dll) per semester & 200,000 \\
\hline Biaya Pembelian peralatan kuliah (tas, sepatu, dII) per semester & 375,000 \\
\hline Biaya perawatan peralatan kuliah (laptop, printer, dll) & 923,333 \\
\hline $\begin{array}{l}\text { Biaya transportasi untuk penyelesaian akademik dan Administrasi UT } \\
\text { pusat/UPBJJ setempat }\end{array}$ & 592,105 \\
\hline Biaya internet untuk kuliah online per semester & 624,233 \\
\hline Biaya makan/snack per semester & 269,444 \\
\hline Biaya Penginapan per semester & 700,000 \\
\hline Jumlah tanggungan/ keluarga yang dibiayai per semester & $8,694,375$ \\
\hline \multicolumn{2}{|l|}{ Pembiayaan Lain-lain } \\
\hline \multicolumn{2}{|l|}{ Semester 2} \\
\hline Biaya Pembelian buku mata kuliah per semester di luar modul & 207,895 \\
\hline Biaya Pembelian alat tulis (termasuk tinta printer, kertas dll) per semester & 180,263 \\
\hline Biaya Pembelian peralatan kuliah (tas, sepatu, dII) per semester & 289,286 \\
\hline Biaya perawatan peralatan kuliah (laptop, printer, dll) & 250,000 \\
\hline $\begin{array}{l}\text { Biaya transportasi untuk penyelesaian akademik dan Administrasi UT } \\
\text { pusat/UPBJJ setempat }\end{array}$ & 426,316 \\
\hline Biaya internet untuk kuliah online per semester & 625,474 \\
\hline Biaya makan/snack per semester & 277,778 \\
\hline Biaya Penginapan per semester & 350,000 \\
\hline Jumlah tanggungan/ keluarga yang dibiayai per semester & $8,694,375$ \\
\hline \multicolumn{2}{|l|}{ Pembiayaan Lain-lain } \\
\hline \multicolumn{2}{|l|}{ Semester 3} \\
\hline Biaya Pembelian buku mata kuliah per semester di luar modul & 217,105 \\
\hline Biaya Pembelian alat tulis (termasuk tinta printer, kertas dll) per semester & 210,526 \\
\hline Biaya Pembelian peralatan kuliah (tas, sepatu, dII) per semester & 292,308 \\
\hline Biaya perawatan peralatan kuliah (laptop, printer, dll) & 146,667 \\
\hline $\begin{array}{l}\text { Biaya transportasi untuk penyelesaian akademik dan Administrasi UT } \\
\text { pusat/UPBJJ setempat }\end{array}$ & 431,250 \\
\hline $\begin{array}{l}\text { Biaya transportasi menuju tempat bimbingan/ dosen pembimbing per } \\
\text { semester }\end{array}$ & 497,222 \\
\hline Biaya internet untuk kuliah online per semester & 643,895 \\
\hline Biaya makan/snack per semester & 277,778 \\
\hline Biaya Penginapan per semester & 350,000 \\
\hline Jumlah tanggungan/ keluarga yang dibiayai per semester & $8,694,375$ \\
\hline Pembiayaan Lain-lain & 200,000 \\
\hline
\end{tabular}


Tabel 2. Lanjutan

\begin{tabular}{lr}
\hline Pertanyaan & Rata-Rata \\
\hline Semester 4 & \\
Biaya Pembelian buku mata kuliah per semester di luar modul & 483,947 \\
Biaya Pembelian alat tulis (termasuk tinta printer, kertas dIII) per semester & 350,000 \\
Biaya Pembelian peralatan kuliah (tas, sepatu, dII) per semester & 196,154 \\
Biaya perawatan peralatan kuliah (laptop, printer, dII) & 209,091 \\
Biaya transportasi untuk penyelesaian akademik dan Administrasi UT & $1,083,333$ \\
pusat/UPBJJ setempat & \\
Biaya transportasi menuju tempat bimbingan/ dosen pembimbing per & 728,947 \\
semester & \\
Biaya internet untuk kuliah online per semester & 657,368 \\
Biaya makan/snack per semester & 394,444 \\
Biaya Penginapan per semester & 480,000 \\
Jumlah tanggungan/ keluarga yang dibiayai per semester & $8,681,250$ \\
Pembiayaan Lain-lain & $2,562,500$ \\
\hline Sumber: Hasil penelitian, diolah penulis (2013).
\end{tabular}

Untuk biaya variabel, rata-rata nilai tertinggi berdasarkan hasil penelitian disimpulkan bahwa semester 4 memerlukan banyak biaya pengeluaran dibandingkan semester yang lainnya. Adapun biaya rata-rata tertinggi yakni biaya tanggungan keluarga, yang berkisar sebesar Rp 8.694.375,-Sedangkan biaya rata-rata terendah yakni pada biaya perawatan peralatan kuliah (laptop, printer, dan lain-lain) per semester yakni sebesar Rp 146.667,--. Adapun biaya tertinggi yang dikeluarkan salah satu responden di pulau Jawa untuk pernyataan biaya variabel adalah biaya tanggungan keluarga, yang mencapai sebesar Rp 13.685.000,-. Sementara untuk pernyataan biaya tetap paling rendah yang dikemukakan salah satu responden yakni pada pernyataan nomor 13 terkait dengan besaran biaya internet yang hanya sebesar Rp 50.000 .

Untuk opportunity cost, mahasiswa mengaku merasa tidak kehilangan kesempatan untuk bekerja selama mengikuti perkuliahan di PPs UT, dikarenakan sistem kuliah online serta tutorial tatap muka (TTM) yang diadakan hari Sabtu dan Minggu tidak mengganggu jadwal pekerjaan mereka. Akan tetapi beberapa diantara responden mengaku kehilangan kesempatan untuk bekerja dan kehilangan mendapatkan penghasilan tambahan. Sementara itu, untuk masalah biaya, responden menganggap biaya kuliah di UT wajar, akan tetapi biaya diluar SPP yang mahal, seperti biaya sidang dan TTM. Untuk perencanaan pembiayaan pendidikan pascasarjana, berusaha mempersiapkan dana pendidikan dengan cara menabung. Selain hal di atas, ada juga mahasiswa yang mengaku mengajukan pinjaman untuk membiayai perkuliahan serta dana dari penghasilan tambahan seperti dana sertifikasi.

\section{b. Luar Pulau Jawa}

Mahasiswa yang mengisi kuesioner dan dapat diolah yang berasal dari Pulau Jawa terdiri atas 54 mahasiswa, yakni berasal dari UPBJJ UT Samarinda, UPBJJ UT Bandar Lampung, dan UPBJJ UT Palangkaraya. Hasil penelitian terkait komponen biaya tetap (fixed cost), dimana masingmasing item dan jumlah pernyataan berbeda di setiap semesternya untuk mahasiswa PPs UT sebagai responden. 
Gambaran terkait dengan rata-rata biaya tetap (fixed cost) yang dikeluarkan oleh mahasiswa untuk masing-masing semester, yakni dari semester 1 sampai dengan semester 4 dapat dijabarkan pada Tabel 3.

Tabel 3. Rata-Rata Biaya Tetap (Fixed Cost) Mahasiswa UPBJJ UT Luar Pulau Jawa

\begin{tabular}{lr}
\hline Pertanyaan & Rata-Rata (Rp) \\
\hline Semester 1 & \\
Biaya Tes Masuk/ Admisi & 399.000 \\
Biaya Registrasi Per Semester/ SPP & 6.238 .889 \\
Biaya mengikuti Kegiatan Orientasi Mahasiswa Baru (OSMB) & 350.000 \\
Biaya Registrasi Ulang Mata Kuliah & 768.421 \\
Biaya seminar per semester & 1.060 .000 \\
Biaya mengikuti perkuliahan umum per semester & 1.350 .000 \\
Biaya mengikuti Tutorial Tatap Muka (TTM) & 3.580 .000 \\
Semester 2 & \\
Biaya Registrasi Per Semester/ SPP & $6,209,615$ \\
Biaya Registrasi Ulang Mata Kuliah & 764.706 \\
Biaya seminar per semester & 1.120 .000 \\
Biaya mengikuti perkuliahan umum per semester & 1.322 .222 \\
Biaya mengikuti Tutorial Tatap Muka (TTM) & 4.462 .069 \\
Semester 3 & \\
Biaya Registrasi Per Semester/ SPP & 6.211 .321 \\
Biaya Registrasi Ulang Mata Kuliah & 871.429 \\
Biaya seminar per semester & 1.376 .000 \\
Biaya mengikuti perkuliahan umum per semester & 1.136 .667 \\
Biaya mengikuti Tutorial Tatap Muka (TTM) & 4.438 .235 \\
Semester 4 & \\
Biaya Registrasi Per Semester/ SPP & 6.200 .000 \\
Biaya Registrasi Ulang Mata Kuliah & 1.000 .000 \\
Biaya seminar per semester & 2.057 .143 \\
Biaya mengikuti perkuliahan umum per semester & 837.500 \\
Biaya mengikuti Tutorial Tatap Muka (TTM) & 3.266 .667 \\
Biaya BTR 1 & 2.497 .222 \\
Biaya BTR 2 & 2.626 .563 \\
Biaya Ujian Sidang & 5.292 .105 \\
Biaya wisuda & 3.662 .500 \\
\hline Sumber: Hasil penelitian, diolah penulis (2013). & \\
& \\
&
\end{tabular}

Rata-rata nilai tertinggi berdasar tabel di atas, selama 4 semester disimpulkan bahwa semester 4 memerlukan banyak biaya pengeluaran dibandingkan semester yang lainnya. Adapun biaya rata-rata tertinggi yakni untuk pembayaran SPP mahasiswa, yang berkisar sebesar Rp 6.300.000 (pembulatan). Sedangkan biaya rata-rata terendah yakni pada Biaya mengikuti Kegiatan Orientasi Mahasiswa Baru (OSMB) yakni sebesar Rp 350.000. Adapun biaya tertinggi yang dikeluarkan salah satu responden di luar pulau Jawa untuk pernyataan biaya tetap adalah biaya ujian sidang, yang mencapai sebesar Rp 12.000.000. Sementara untuk pernyataan biaya tetap paling rendah yang dikemukakan salah satu responden yakni pada pernyataan nomor 6 terkait dengan besaran biaya mengikuti perkuliahan umum per semester yang hanya sebesar Rp 100.000,-- 
Sementara itu, untuk hasil penelitian biaya variabel, rata-rata nilai tertinggi selama 4 semester disimpulkan bahwa semester 4 memerlukan banyak biaya pengeluaran dibandingkan semester yang lainnya. Adapun biaya rata-rata tertinggi yakni biaya tanggungan keluarga, yang berkisar sebesar Rp 11.690.476,--. Sedangkan biaya rata-rata terendah yakni pada biaya pembelian alat tulis (termasuk tinta printer, kertas dan lain-lain) per semester yakni sebesar Rp 323.500,-Gambaran terkait dengan rata-rata biaya variabel (variable cost) yang dikeluarkan oleh mahasiswa untuk masing-masing semester, yakni dari semester 1 sampai dengan semester 4 dapat dijabarkan pada Tabel 4.

Tabel 4. Rata-Rata Biaya Variabel (Variable Cost) Mahasiswa UPBJJ UT Luar Pulau Jawa

\begin{tabular}{lr}
\hline Pertanyaan & Rata-Rata (Rp) \\
\hline Semester 1 & \\
Biaya Pembelian buku mata kuliah per semester di luar modul & 538.750 \\
Biaya Pembelian alat tulis (termasuk tinta printer, kertas dII) per semester & 476.400 \\
Biaya Pembelian peralatan kuliah (tas, sepatu, dll) per semester & 462.821 \\
Biaya perawatan peralatan kuliah (laptop, printer, dll) & 775.000 \\
Biaya transportasi untuk penyelesaian akademik dan Administrasi UT & 1.883 .333 \\
pusat/UPBJJ setempat & \\
Biaya internet untuk kuliah online per semester & 686.737 \\
Biaya makan/snack per semester & 408.333 \\
Biaya Penginapan per semester & 1.060 .000 \\
Jumlah tanggungan/ keluarga yang dibiayai per semester & 11.690 .476 \\
Pembiayaan Lain-lain & 1.581 .250 \\
Semester 2 & \\
Biaya Pembelian buku mata kuliah per semester di luar modul & 412.821 \\
Biaya Pembelian alat tulis (termasuk tinta printer, kertas dII) per semester & 350.568 \\
Biaya Pembelian peralatan kuliah (tas, sepatu, dll) per semester & 354.839 \\
Biaya perawatan peralatan kuliah (laptop, printer, dll) & 340.789 \\
Biaya transportasi untuk penyelesaian akademik dan Administrasi UT & 1.286 .111 \\
pusat/UPBJJ setempat & \\
Biaya internet untuk kuliah online per semester & 613.750 \\
Biaya makan/snack per semester & 334.483 \\
Biaya Penginapan per semester & 875.000 \\
Jumlah tanggungan/ keluarga yang dibiayai per semester & 10.947 .368 \\
Pembiayaan Lain-lain & 2.225 .000 \\
Semester 3 & \\
Biaya Pembelian buku mata kuliah per semester di luar modul & 450.000 \\
Biaya Pembelian alat tulis (termasuk tinta printer, kertas dll) per semester & 323.500 \\
Biaya Pembelian peralatan kuliah (tas, sepatu, dll) per semester & 337.879 \\
Biaya perawatan peralatan kuliah (laptop, printer, dll) & 345.455 \\
Biaya transportasi untuk penyelesaian akademik dan Administrasi UT & 1.000 .000 \\
pusat/UPBJJ setempat & \\
Biaya transportasi menuju tempat bimbingan/ dosen pembimbing per semester & 2.705 .263 \\
Biaya internet untuk kuliah online per semester & 623.810 \\
Biaya makan/snack per semester & 375.806 \\
Biaya Penginapan per semester & 1.020 .000 \\
\hline & \\
\hline & \\
& \\
& \\
& \\
&
\end{tabular}


Tabel 4. Lanjutan

\begin{tabular}{lr}
\hline Pertanyaan & Rata-Rata (Rp) \\
\hline Jumlah tanggungan/ keluarga yang dibiayai per semester & 10.985 .000 \\
Pembiayaan Lain-lain & 3.300 .000 \\
Semester 4 & \\
Biaya Pembelian buku mata kuliah per semester di luar modul & 715.385 \\
Biaya Pembelian alat tulis (termasuk tinta printer, kertas dII) per semester & 384.146 \\
Biaya Pembelian peralatan kuliah (tas, sepatu, dll) per semester & 377.273 \\
Biaya perawatan peralatan kuliah (laptop, printer, dll) & 332.353 \\
Biaya transportasi untuk penyelesaian akademik dan Administrasi UT & 4.519 .355 \\
pusat/UPBJJ setempat & \\
Biaya transportasi menuju tempat bimbingan/ dosen pembimbing per semester & 2.357 .576 \\
Biaya internet untuk kuliah online per semester & 648.684 \\
Biaya makan/snack per semester & 351.852 \\
Biaya Penginapan per semester & 1.023 .077 \\
Jumlah tanggungan/ keluarga yang dibiayai per semester & 10.553 .333 \\
Pembiayaan Lain-lain & 2.575 .000 \\
\hline Sumber: Hasil penelitian, dioh penulis (2013).
\end{tabular}

Sumber: Hasil penelitian, diolah penulis (2013).

Adapun biaya tertinggi yang dikeluarkan salah satu responden di luar pulau Jawa untuk pernyataan biaya variabel adalah biaya tanggungan keluarga, yang mencapai sebesar Rp 60.000 .000 ,-. Sementara untuk pernyataan biaya tetap paling rendah yang dikemukakan salah satu responden yakni pada pernyataan nomor 17 terkait dengan besaran biaya lain-lain yang hanya sebesar Rp 25,000. Rata-rata nilai tertinggi berdasar tabel di atas, selama 4 semester disimpulkan bahwa semester 4 memerlukan banyak biaya pengeluaran dibandingkan semester yang lainnya. Adapun biaya rata-rata tertinggi yakni biaya tanggungan keluarga, yang berkisar sebesar Rp 11.690.476,-. Sedangkan biaya rata-rata terendah yakni pada biaya pembelian alat tulis (termasuk tinta printer, kertas dan lain-lain) per semester yakni sebesar Rp 323.500,-. Adapun biaya tertinggi yang dikeluarkan salah satu responden di luar pulau Jawa untuk pernyataan biaya variabel adalah biaya tanggungan keluarga, yang mencapai sebesar Rp 60.000.000,-. Sementara untuk pernyataan biaya tetap paling rendah yang dikemukakan salah satu responden yakni pada pernyataan nomor 17 terkait dengan besaran biaya lain-lain yang hanya sebesar Rp 25.000,--

Untuk opportunity cost, mahasiswa mengaku merasa tidak kehilangan kesempatan untuk bekerja selama mengikuti perkuliahan di PPs UT, dikarenakan sistem kuliah online serta tutorial tatap muka (TTM) yang diadakan hari Sabtu dan Minggu tidak mengganggu jadwal pekerjaan mereka. Akan tetapi beberapa diantara responden mengaku kehilangan kesempatan untuk bekerja dan kehilangan mendapatkan penghasilan tambahan. Sementara itu, untuk masalah biaya, responden menganggap biaya kuliah di UT wajar, akan tetapi biaya diluar SPP yang mahal, seperti biaya sidang dan TTM. Untuk perencanaan pembiayaan pendidikan pascasarjana, berusaha mempersiapkan dana pendidikan dengan cara menabung. Selain hal di atas, ada juga mahasiswa yang mengaku dibantu keluarga, mengajukan pinjaman untuk membiayai perkuliahan serta dana dari penghasilan tambahan seperti dana sertifikasi.

\section{PEMBAHASAN}

Setelah dihitung rata-rata serta nilai minimal dan maksimal, biaya tetap yang dikeluarkan oleh mahasiswa selama mengikuti perkuliahan, dapat disimpulkan bahwa biaya yang dibayarkan 
setiap semesternya sama, yakni biaya SPP, TTM, registrasi ulang mata kuliah, seminar, dan perkuliahan umum; kecuali untuk beberapa biaya yang memang berbeda dan hanya ada pada semester tertentu. Misalnya untuk biaya tes masuk dan orientasi mahasiswa baru hanya satu kali dibayarkan yakni pada saat awal semester/ semester pertama. Sementara untuk biaya BTR 1 \& 2 , biaya sidang serta biaya wisuda dibayarkan satu kali pada semester 4.

Hal ini juga dikemukakan Majidn (2007) terkait dengan biaya tetap, bahwa biaya tetap (fixed cost) adalah jenis biaya yang selama kisaran waktu operasi tertentu atau tingkat kapasitas produksi tertentu selalu tetap jumlahnya atau tidak berubah walaupun volume produksi berubah. Biaya tetap adalah biaya yang umumnya selalu konstan, bahkan di masa sulit. Biaya tetap tidak terpengaruh oleh perubahan-perubahan dalam aktivitas operasi sampai pada kondisi tertentu, kondisi dimana sesuai dengan kapasitas yang tersedia. Meskipun berganti semester, jumlah biaya yang harus dibayarkan tetap sama. Adapun perbedaan SPP yang ditetapkan sesuai dengan tahun masuk angkatan, dan skema selanjutnya adalah besaran jumlah yang harus dibayarkan sama sampai mahasiswa tersebut lulus kuliah. Selain itu, hal ini juga sejalan dengan pernyataan Raharja dan Manurung (2006), dimana biaya tetap adalah biaya yang besarnya tidak tergantung pada jumlah produksi, misalnya biaya batang modal, gaji pegawai, dan tetap harus dikeluarkan dalam jumlah yang sama pada saat perusahaan tidak berproduksi (Q=0). Pindyck dan Rubinfield (2009) mengemukakan bahwa biaya tetap adalah biaya yang tidak dapat divariasikan dengan tingkat output dan dapat dihilangkan jika perusahaan ditutup (dihilangkan).

Setelah dihitung rata-rata serta nilai minimal dan nilai maksimal untuk biaya variabel yang dikeluarkan mahasiswa selama mengikuti perkuliahan, dapat ditarik kesimpulan bahwa biaya yang dikeluarkan setiap semesternya berbeda-beda, tergantung dengan ada/tidak adanya kegiatan yang menyebabkan pengeluaran mahasiswa bertambah. Jarak tempuh mahasiswa ke tempat perkuliahan tatap muka (TTM) juga berpengaruh terhadap pengeluaran biaya variabel. Jarak tempuh terjauh menurut pengisian identitas responden yakni $800 \mathrm{~km}$. Hal ini sesuai dengan pendapat Nafarin $(2004)^{2}$ biaya variabel adalah biaya yang jumlahnya berubah sejalan dengan perubahan volume kegiatan tetapi biaya per unit tidak berubah walaupun volume kegiatan berubah. Hal ini juga sejalan dengan pendapat Raharja dan Manurung (2006) yang mengemukakan bahwa biaya variabel adalah biaya yang besarnya tergantung pada tingkat produksi, misal biaya upah buruh, bahan baku, dan lain-lain. Samuelson dan Nordhaus (2004) mengemukakan bahwa biaya variabel adalah biaya yang berubah sesuai dengan besarnya output, dimana ketika output $=0$, biaya variabel (VC) berada pada angka 0. Pindyck dan Rubinfield (2009) mengemukakan bahwa biaya variabel adalah biaya yang bervariasi sesuai dengan variabel output-nya

Setelah dihitung rata-rata serta nilai minimal dan maksimal, biaya kesempatan yang hilang (opportunity cost) akibat mengikuti perkuliahan di PPs UT, dapat disimpulkan bahwa mahasiswa merasa tidak terdapat opportunity cost yang diakibatkan oleh sistem perkuliahan jarak jauh UT. Mereka berpendapat bahwa dengan mengikuti UPBJJ UT, mahasiswa masih dapat melakukan aktivitas pekerjaan seperti sedia kala dikarenakan sistem perkuliahan online serta tatap muka yang diselenggarakan setiap Sabtu dan Minggu. Hal ini sesuai dengan pendapat yang dikemukakan oleh Darsono (2005), dimana dikemukakan bahwa opportunity cost yaitu manfaat yang dikorbankan pada saat memilih satu di antara beberapa alternatif kesempatan untuk memperoleh benefit laba atau keuntungan. Selain itu, hal ini sejalan dengan pendapat Raharja dan Manurung (2006), dimana dikemukakan bahwa biaya kesempatan adalah kesempatan untuk memperoleh sesuatu yang hilang karena telah memilih alternatif lain. Pindyck dan Rubinfield (2009) mengemukakan bahwa biaya 
kesempatan atau biaya peluang adalah biaya yang berasal dari peluang-peluang yang dilewatkan dengan tidak menempatkan sumber daya ke dalam nilai penggunaan tertingginya.

Selain itu, dalam menempuh pendidikan di PPs UT, mahasiswa banyak yang menabung guna mempersiapkan dana pendidikan mereka. Hal ini senada dengan Dror (1975), Perencanaan Pendidikan adalah suatu proses mempersiapkan seperangkat keputusan untuk kegiatan-kegiatan di masa depan yang di arahkan untuk mencapai tujuan-tujuan dengan cara-cara optimal untuk pembangunan ekonomi dan social secara menyeluruh dari suatu Negara.

Beberapa hal yang perlu mendapat perhatian dalam menyusun rencana keuangan sekolah sebagai berikut.

a. Perencanaan harus realistis

b. Perlunya koordinasi dalam perencanaan

c. Perencanaan harus berdasarkan pengalaman, pengetahuan, dan intuisi.

d. Perencanaan yang didasarkan penelitian

e. Perencanaan sesuai dengan tujuan.

Masalah lain yang sering muncul pada sistem pendidikan luar Jawa tentunya berbeda dengan wilayah di Pulau Jawa. Permasalahannya diantaranya adalah:

a. Minat Baca (sense of reading)

b. Infrastruktur Pendidikan

c. Sistem Pengajaran

\section{KESIMPULAN}

a. Rata-rata nilai tertinggi pembiayaan pendidikan dapat disimpulkan bahwa semester 4 memerlukan banyak biaya pengeluaran dibandingkan semester yang lainnya. Adapun biaya rata-rata tertinggi adalah untuk pembayaran SPP mahasiswa, yang berkisar sebesar Rp 6.300.000,- (pembulatan). Sedangkan biaya rata-rata terendah yakni pada biaya kegiatan mengikuti Kegiatan Orientasi Mahasiswa Baru (OSMB) yaitu sebesar Rp 350.000,-. Ada biaya tertinggi yang dikeluarkan salah satu responden untuk pernyataan biaya tetap yaitu untuk biaya untuk ujian sidang yakni mencapai Rp 12.000.000,-. Sementara untuk pernyataan biaya tetap paling rendah yang dikemukakan salah satu responden yang terkait dengan besaran biaya mengikuti perkuliahan umum per semester yaitu sebesar Rp 100.000,--

b. Rata-rata nilai pembiayaan tertinggi selama 4 semester mengikuti pembelajaran di PPs - UT disimpulkan adalah pada semester 4 dibandingkan dengan semester lainnya. Adapun biaya rata-rata tertinggi yakni biaya tanggungan keluarga, yang berkisar sebesar Rp 11.702.917,-Sedangkan biaya rata-rata terendah yakni pada biaya pembelian alat tulis (termasuk tinta printer, kertas dan lain-lain) per semester yakni sebesar Rp 304.741,--. Adapun biaya tertinggi yang dikeluarkan salah satu responden untuk pernyataan biaya tetap adalah biaya tanggungan keluarga, yang mencapai sebesar Rp 60.000.000,-. Sementara untuk pernyataan biaya tetap paling rendah yang dikemukakan salah satu responden yakni pada pernyataan nomor 17 terkait dengan besaran biaya yang hanya sebesar Rp 25.000,--

c. Responden merasa tidak kehilangan kesempatan untuk bekerja selama mengikuti perkuliahan di PPs UT, dikarenakan sistem kuliah online serta tutorial tatap muka (TTM) yang diadakan hari Sabtu Minggu tidak mengganggu jadwal pekerjaan mereka. Akan tetapi beberapa diantara responden mengaku kehilangan kesempatan untuk bekerja.

d. Responden merasa tidak kehilangan kesempatan untuk mendapat penghasilan selama mengikuti perkuliahan di PPs UT, dikarenakan sistem kuliah online serta tutorial tatap muka 
(TTM) yang diadakan hari Sabtu Minggu tidak mengganggu jadwal pekerjaan mereka. Akan tetapi beberapa diantara responden mengaku kehilangan kesempatan untuk mendapat penghasilan.

e. Responden menganggap bahwa biaya di UT wajar, sebagian menganggap biaya perkuliahan di UT mahal. Hal ini disebabkan karena membengkaknya pengeluaran biaya variabel.

f. Responden menabung untuk membiayai biaya pendidikan. Mereka membuat perencanaan matang dengan menyisihkan sebagian penghasilan mereka guna membiayain pendidikan PPs UT, dan menyimpannya dalam tabungan.

\section{REFERENSI}

Belawati, T. (1999). Sistem pendidikan terbuka dan jarak jauh: Suatu reformasi pola pikir, Technical paper presented at the seminar pendidikan jarak jauh dalam reformasi pendidikan (seminar on distance education in educational reform), Graduation I-1999 Universitas Terbuka.

Dror, Y. (1975). Definisi perencanaan pendidikan, diundah Maret 2013 dari http://winamartiana.wordpress.com/ 2011/09/25/definisi-perencanaan-pendidikan/,

Majidn, Asep. (2007). Tinjauan pustaka: Konsep biaya. Tersedia online: lib.unikom.ac.id/download.php? id=16751. Diunduh April 2013.

Nafarin M. (2004). Penganggaran perusahaan, Jakarta: Salemba empat.

Oshima. (2001). Penelitian belajar jarak jauh di international datra corporation (IDC) tahun 1998, diunduh Mei 2013 dari http:///rristian-nuki15.blogspot.com/2009/03/pembiayaan-pendidikanjarak-jauh.html.

Pindyck, Robert S. \& Daniel L. Rubinfeld. (2009). Mikroekonomi Jilid 1, Edisi Keenam (terjemahan). Jakarta: Indeks.

Raharja, Pratama dan Mandala Mnurung. (2006). Teori ekonomi mikro: Suatu pengantar (Edisi 4). Jakarta: Lembaga Penerbit FEUI.

Samuelson \& Nordhaus. (2004). Ilmu mikroekonomi. Edisi 17. Jakarta: Media Global Edukasi. 